\title{
Feeding selectivity of larval walleye pollock Theragra chalcogramma in the oceanic domain of the Bering Sea
}

\author{
Nicola Hillgruber ${ }^{1, *}$, Lewis J. Haldorson ${ }^{1}$, Augustus J. Paul ${ }^{2}$ \\ ${ }^{1} J u n e a u$ Center, School of Fisheries and Ocean Sciences, University of Alaska Fairbanks, 11120 Glacier Highway, Juneau, \\ Alaska 99801, USA \\ ${ }^{2}$ Institute of Marine Science, Seward Marine Center, University of Alaska Fairbanks, Seward, Alaska 99664, USA
}

\begin{abstract}
Feeding of larval walleye pollock was examined with respect to density and distribution of micro- and mesozooplanktonic prey $(<500 \mu \mathrm{m})$ at 6 depths in the oceanic domain of the Bering Sea to determine if first-feeding larvae select among available prey and to assess their foraging environment in comparison to other locations where walleye pollock spawn. At $30 \mathrm{~m}$ depth, walleye pollock larvae and copepod nauplii occurred at maximum densities of 106.6 ind. $100 \mathrm{~m}^{-3}$ and 26.3 ind $1^{-1}$, respectively. First-feeding walleye pollock larvae $(3.5$ to $6.5 \mathrm{~mm})$ fed exclusively on copepod nauplii and copepod eggs. Among copepod nauplii, larvae selected for Metridia sp. and Microcalanus sp. but against Oithona similis, even though the latter was the most abundant prey taxon in the study area. Of the nauplii ingested by larval walleye pollock, there was evidence of selection for larger nauplii within Metridia sp., Microcalanus sp., and $O$. similis. In addition, larvae preferred Stages III to V of calanoid nauplii. Larvae at $30 \mathrm{~m}$ depth had the highest incidence of feeding $(97.5 \%)$ and number of prey items $\left(4.6\right.$ larva $\left.^{-1}\right)$ ingested. Although the $30 \mathrm{~m}$ depth stratum provided best physical and foraging conditions, the overall low percentage of feeding larvae and low numbers of prey consumed suggest that foraging conditions for larval walleye pollock at the time of sampling were below saturation feeding levels.
\end{abstract}

KEY WORDS: Walleye pollock larvae $\cdot$ Feeding $\cdot$ Nauplii $\cdot$ Prey selection $\cdot$ Bering Sea

\section{INTRODUCTION}

Survival of larval fishes is regulated largely through predation and the effects of suboptimal food levels, such as starvation and reduced growth rates (Houde 1987). Starvation may be a direct cause of mortality for only a short time after the onset of feeding. However, even small declines in growth rates will prolong the duration of the earliest life stages that experience the highest mortality rates. Therefore, the foraging environment of larval fishes, especially during first feeding, may play an important role in recruitment variability (Crecco \& Savoy 1987).

Description of the foraging environment encountered by fish larvae has often lacked the resolution

- Present address: Biologische Anstalt Helgoland, Notkestraße 31, D-22607 Hamburg, Germany necessary to evaluate the role of prey availability in feeding and growth. The abundance of planktonic prey utilized by fish larvae is not adequately assessed by sampling zooplankton in higher size ranges $(>250 \mu \mathrm{m})$ (Frank 1988). Even within the microzooplankton it is necessary to measure prey availability in the size ranges utilized by fish larvae (Frank \& Leggett 1986) because fish larvae discriminate among prey taxa based on size, swimming behavior, capturability, visibility and predator preference (Peterson \& Ausubel 1984, Jenkins 1987, Pryor \& Epifanio 1993). Consequently, evaluating the suitability of the foraging environment for larval fishes requires a detailed understanding of their feeding patterns and preferences.

Walleye pollock Theragra chalcogramma is one of the most abundant fish species in the Bering Sea, constituting nearly $70 \%$ of the total biomass of harvested groundfish in the eastern Bering Sea and $85 \%$ in the 
Fig. 1. Study area in the oceanic domain of the Bering Sea. (-) Sampling station on April 20 . 1992

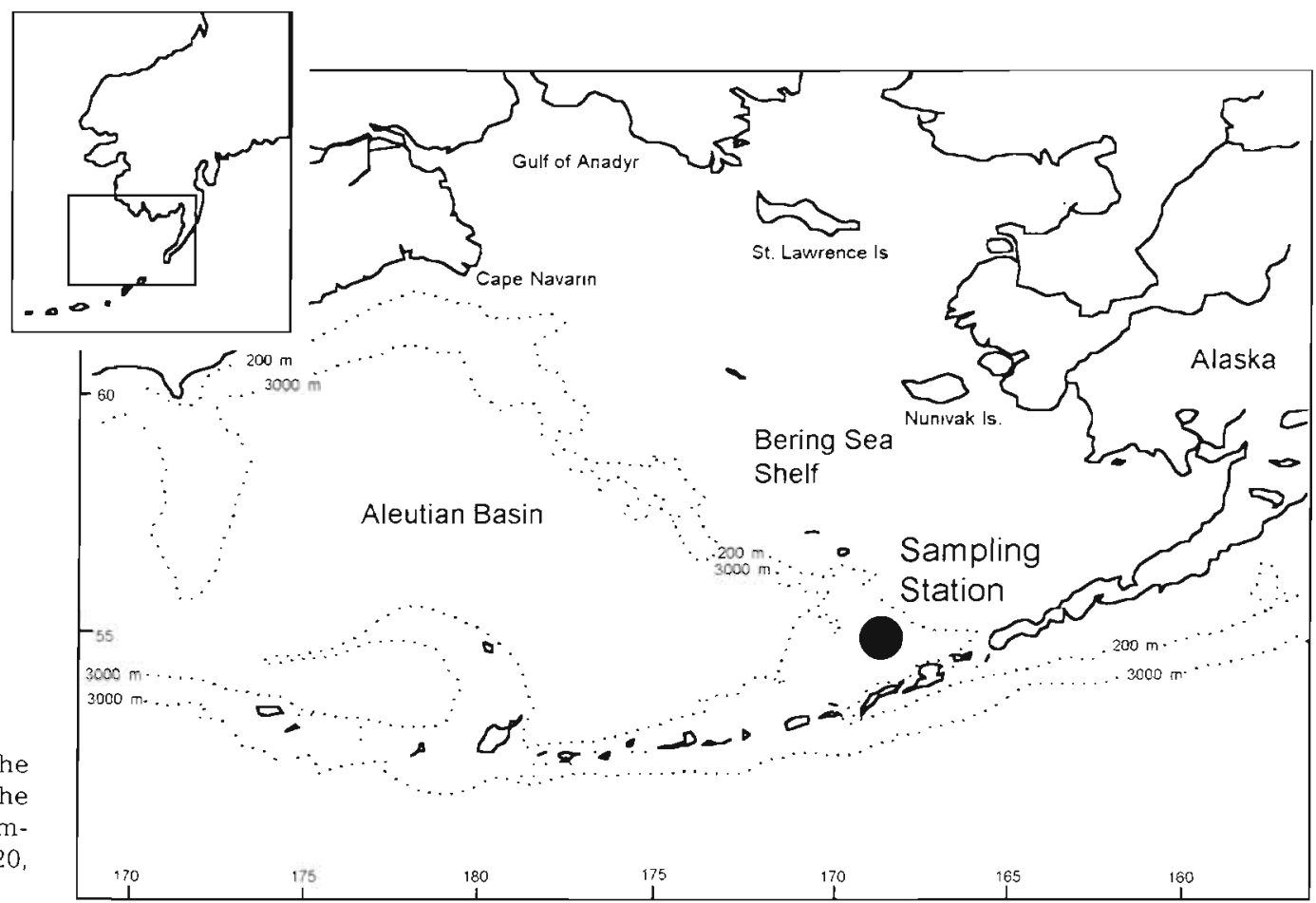

western Bering Sea (Springer 1992). In the eastern Bering Sea, eggs of walleye pollock are spawned first in oceanic waters over the Aleutian Basin and continental slope and later in the year over the shelf (Hinckley 1987). Since the southeastern Bering Sea is effectively divided by the middle shelf frontal zone into the oceanic and the middle shelf domains (Kinder \& Schumacher 1981), larvae from these eggs hatch into quite different production systems (Cooney \& Coyle 1982). Previous studies have focussed on the feeding ecology of walleye pollock larvae over the shelf in the middle shelf domain (Clarke 1984, Dagg et al. 1984, Nishiyama et al. 1986, Grover 1991). However, little is known about feeding habits of walleye pollock larvae in the oceanic domain of the Bering Sea or the role prey availability may play in determining survival of larvae and recruitment dynamics

In 1992, we sampled recently hatched walleye pollock larvae over the deep water of the outer continental shelf of the Bering Sea. We also sampled the foraging environment. Our objectives were to determine if first-feeding walleye pollock larvae select among available prey by size and taxa and to assess the foraging environment in relation to other locations where walleye pollock larvae are found.

\section{MATERIAL AND METHODS}

Field methods. Samples were collected on board the NOAA RV 'Miller Freeman' during midday (10:46 to
$14: 58 \mathrm{~h}$ ) on April 20, 1992, at 1 station $\left(55^{\circ} 01^{\prime} 09^{\prime \prime} \mathrm{N}\right.$, $168^{\circ} 19^{\prime} 96^{\prime \prime} W_{i} 1900 \mathrm{~m}$ bottom depth) in the southeastern Bering Sea (Fig. 1). Microzooplankton and physical data were collected using a rosette sampler equipped with 101 Niskin bottles and a CTD system. Microzooplankton were sampled at $10,20,30,50,70$, and $90 \mathrm{~m}$ depth, with 3 replicates per depth. Since the predominant food items for walleye pollock larvae (copepod nauplii and eggs) are $\geq 100 \mu \mathrm{m}$ (Canino et al. 1991, Kendall \& Nakatani 1992), we chose a $64 \mu \mathrm{m}$ bag net for filtering the microzooplankton samples. The concentrated samples were preserved in $5 \%$ buffered formalin-seawater solution. A Seabird CTD-system recorded conductivity, temperature, and pressure from 0 to $90 \mathrm{~m}$ depth simultaneously with microzooplankton sampling. Ichthyoplankton were collected at 10, 20, 30, 50,70 , and $90 \mathrm{~m}$ depth with a $1 \mathrm{~m}^{2}$ MOCNESS (Multiple Opening-Closing Net and Environmental Sensing System; Wiebe et al. 1976). The gear was equipped with $505 \mu \mathrm{m}$ mesh, which is standard size (Smith \& Richardson 1977) and is known to catch Theragra chalcogramma larvae efficiently (Shima \& Bailey 1994). Three replicates were collected at each depth. Three MOCNESS casts were taken, with 2 depths sampled per cast. Upon retrieval the nets were thoroughly washed, codends detached and the samples rinsed through a $335 \mu \mathrm{m}$ sieve. Concentrated samples were fixed in $10 \%$ buffered formalin-seawater solution.

Laboratory methods. Copepod nauplii from 3 replicates at each depth were counted, measured to the nearest $10 \mu \mathrm{m}$ with an ocular micrometer and identi- 
fied to the lowest possible taxon. The total lengths (TL; length of carapace and abdomen, excluding terminal spines) of 278 Oithona similis (cyclopoid) nauplii were measured at 2 depths, $30 \mathrm{~m}$ (Replicate 1) and $70 \mathrm{~m}$ (Replicate 1), respectively, and the naupliar stages were identified based on characteristics determined by Sazhina (1985). Calanoid nauplii were counted and TL and carapace lengths (CL) were measured in all replicates, whenever possible. Naupliar stages were determined for Metridia sp. and Pseudocalanus sp. nauplii based on TL and characteristic features (Ogilvie 1953). Microcalanus sp. nauplii were staged using TL (Ogilvie 1953). Stages I and II of Metridia sp. and Pseudocalanus sp. nauplii could not be distinguished; they were categorized as calanoids I/II. Calanoid nauplii that could not be identified were listed as calanoids. Concentration was expressed as average numbers $l^{-1}$ from the 3 replicates. Copepod eggs from the environmental samples were not counted.

Within 4 mo after fixation, all fish larvae were removed from each sample under a dissecting microscope $(10 \times)$, identified to species, and counted. Density of larvae was expressed as number $100 \mathrm{~m}^{-3}$. Standard length (SL) of larvae was measured to the nearest $0.1 \mathrm{~mm}$ using a BioQuant image analysis system with a high-resolution video system and a digitizer. No correction was made for shrinkage. Walleye pollock larvae were separated into $0.5 \mathrm{~mm}$ length classes and stored in $50 \%$ isopropyl alcohol.

Larvae for feeding studies were subsampled from each $0.5 \mathrm{~mm}$ size class in each depth stratum. The subsample size was 10 , unless fewer larvae were available. Each larva was positioned on a microscope slide in a drop of distilled water and SL was measured with a dissecting microscope and ocular micrometer. The whole gut tract was removed and placed on a slide in a drop of glycerin. The gut was opened and the contents excised. Each item was measured with an ocular micrometer on a compound microscope to within $10 \mu \mathrm{m}$. The diameter of copepod eggs was measured. Copepod nauplii were identified as Metridia sp., Pseudocalanus sp., Microcalanus sp., calanoids I/II, calanoids, and Oithona similis. CL and TL were measured, and the stages were determined whenever possible

Statistical methods. The null hypothesis that fish larvae and copepod nauplii were evenly distributed among sample depths was tested with single-factor analysis of variance (ANOVA), as was the null hypothesis that length did not differ with depth. If density or size differences were found among depths, Scheffés multiple comparison procedures were conducted to examine pairwise relationships (Sokal \& Rohlf 1981). Prior to statistical testing, data were checked for departure from assumptions of ANOVA. Normal probability plots were used to determine if data were normally distributed. Homoscedasticity was analyzed by plotting mean against variance. Departures from the assumption of homoscedasticity were corrected with a logtransformation and the variates were coded by adding 1 because data to be transformed contained zeros $\left[\log _{10}(Y+1)\right]$ (Sokal \& Rohlf 1981).

CL was regressed against TL in the 3 genera, Metridia sp., Pseudocalanus sp., and Microcalanus sp. This allowed calculation of TL from CL for damaged calanoid nauplii in gut contents.

Prey consumption was described by percent frequency of occurrence $(\% \mathrm{FO})$, percent number $(\% \mathrm{~N})$. and percent volume (\%Vol) (Wallace 1981). The index of relative importance was calculated as

$$
\% \text { IRI }=(\% \mathrm{~N}+\% \text { Vol }) \times \% \mathrm{FO}
$$

to provide a more comprehensive assessment of prey importance (Wallace 1981, Grover 1990). Volume of copepod nauplii was calculated from CL using mensuration formulae (Nishiyama \& Hirano 1983). The overall proportion of prey items and of developmental stages of prey taxa ingested was weighted by the proportion of the pollock population at each depth, so that the overall proportion of a given prey item $(O, j$ was:

$$
O_{j}=\sum_{i=1}^{n}\left(f_{i j} p_{i}\right)
$$

where $f_{i j}$ is frequency of prey item $j$ at any given depth $i_{i} p_{i}$ is proportion of the population at depth $i_{i}$ and $n$ is number of depths.

A chi-squared test of independence was used to test the null hypothesis that the proportion of feeding larvae was uniform with respect to depth or size class. The mean number of food items per larval gut was calculated for all guts that contained food items. The null hypothesis that the number and size of prey items per gut did not differ among depths was tested with ANOVA. The counts were square-root transformed in order to meet the assumptions of ANOVA (Sokal \& Rohlf 1981). If differences were found, Scheffé's multiple comparison procedure was used to test for pairwise relationships.

Feeding selectivity $(L)$ was estimated using $\ln L$ of the Odds Ratio $(O)$ as a measure of selectivity (Gabriel 1978). The ln of the Odds Ratio was used because it meets all criteria for a desirable index of selectivity. It is easy to interpret and calculate, and the significance can be tested statistically. $L$ is symmetrically distributed around a mean of zero and ranges from zero to $+\infty$, in case of positive selection, and zero to $-\infty$, in case of negative selection:

$$
L=\ln (O)=\ln \left(\frac{p_{1} q_{2}}{p_{2} \cdot q_{1}}\right)
$$


where $p_{1}$ is the percentage of diet comprised by a given prey taxon, $p_{2}$ is the percentage of food item in the environment comprised by a given taxon, $q_{1}$ is the percentage of diet comprised by all other prey taxa, $q_{2}$ is the percentage of food item in the environment comprised by all other taxa. The SE of $L$ was calculated as

$$
\mathrm{SE}=\sqrt{\frac{1}{n_{1} \cdot p_{1} \cdot q_{1}}+\frac{1}{n_{2} \cdot p_{2} \cdot q_{2}}}
$$

where $n_{1}$ is the total number of prey in the diet sample and $n_{2}$ is the total number of food organisms in the environmental sample. Since $L$ has a log-normal distribution, the null hypothesis that an observed $L$ is not significantly different from zero, and prey therefore were consumed non-selectively, can be tested. The difference is expressed in terms of standard normal deviates $(Z)$ :

$$
Z=\frac{L_{\text {observed }}-L_{\text {expected }}}{\operatorname{SE}(L)}
$$

where $L_{\text {expected }}=0$.

\section{RESULTS}

\section{Physical environment}

Temperature ranged from about $2.8^{\circ} \mathrm{C}$ at the surface to $3.5^{\circ} \mathrm{C}$ at $90 \mathrm{~m}$ depth, with an increase in temperature at $20 \mathrm{~m}$ depth. Salinity ranged from $32.4 \%$ at the surface to $32.7 \%$ at $90 \mathrm{~m}$ depth, gradually increasing with depth (Fig. 2). No seasonal thermocline was developed.

Fig. 2. Temperature and salinity depth profile at the sampling station, April 20, 1992, in the oceanic domain of the Bering Sea
Table 1 Theragra chalcogramma. Mean densities of walleye pollock larvae $100 \mathrm{~m}^{-3}$ and copepod nauplii $\mathrm{l}^{-1}$ on April 20 , 1992, in the oceanic domain of the Bering Sea. Means and $95 \%$ confidence intervals were calculated from $\log _{10}(X+1)$ transformed variates. Parentheses indicate $95 \%$ confidence intervals

\begin{tabular}{|ccrl|}
\hline $\begin{array}{c}\text { Depth } \\
(\mathrm{m})\end{array}$ & $\begin{array}{c}\text { Walleye pollock larvae } \\
100 \mathrm{~m}^{-3}\end{array}$ & \multicolumn{1}{c|}{ Copepod nauplii $^{-1}$} \\
\hline 10 & $49.85(19.41 ; 128.02)$ & $3.49(0.08 ; 17.67)$ \\
20 & $32.69(11.27 ; 94.85)$ & $10.17(4.90 ; 20.13)$ \\
30 & $106.64(41.39 ; 274.76)$ & $26.27(7.60 ; 85.46)$ \\
50 & $4.74(1.08 ; 20.71)$ & $16.71(11.36 ; 24.37)$ \\
70 & $3.13(1.87 ; 5.23)$ & $15.08(12.78 ; 17.76)$ \\
90 & $1.59(0.29 ; 8.61)$ & $14.53(5.02 ; 39.03)$ \\
\hline
\end{tabular}

\section{Walleye pollock density and size}

Walleye pollock larvae were found at all depth strata sampled and were most dense in the 3 strata nearest the surface, with a peak concentration of 106.6 ind. $100 \mathrm{~m}^{-3}$ at $30 \mathrm{~m}$ depth (Table 1). Differences in concentration among depths were significant $(F=39.33$, $p \leq 0.001$ ). The 3 shallowest and deepest strata formed 2 significantly distinct homogeneous groups (Scheffé's a posteriori).

Mean length of walleye pollock larvae was greatest at $30 \mathrm{~m}$ depth with an average length of $5.3 \mathrm{~mm}$ and lowest at $90 \mathrm{~m}$ depth with $4.3 \mathrm{~mm}$ (Fig. 3). Length differed significantly among depths $(F=23.7, \mathrm{p} \leq 0.001)$, larvae being significantly longer in the upper 3 than in the lower 3 depth strata (Scheffés a posteriori). Since walleye pollock larvae are about 3 to $4 \mathrm{~mm}$ at hatching and start feeding well before yolk-sac absorption (Nishiyama et al. 1986), the larvae in the present study represented first-feeding larvae.

\section{Copepod nauplii density, species, and size composition}

Overall density of copepod nauplii was highest at $30 \mathrm{~m}$ depth (Table 1). Differences in densities among depths were significant $(F=7.677, \mathrm{p} \leq 0.005)$. Taxa included 3 calanoid genera (Metridia sp., Pseudocalanus sp., Microcalanus sp.) and the cyclopoid species Oithona similis. The most common (79\%) species, $O$. similis, varied significantly in number among depths $(F=5.36, p \leq 0.01)$, reaching peak concentrations of $21.5 \mathrm{l}^{-1}$ at $30 \mathrm{~m}$ (Fig. 4). Metridia sp. nauplii were the second most abundant species and also peaked in abundance at $30 \mathrm{~m}$ depth $(F=12.02, \mathrm{p} \leq 0.001)$ (Fig. 4). The density of Pseudocalanus sp. nauplii varied significantly with depth $(F=3.24, p \leq 0.05)$. No Microcalanus $\mathrm{sp}$. nauplii were found at $10 \mathrm{~m}$ depth, but significantly higher numbers occurred at $90 \mathrm{~m}(F=4.17, \mathrm{p} \leq 0.05)$. 
Frequency
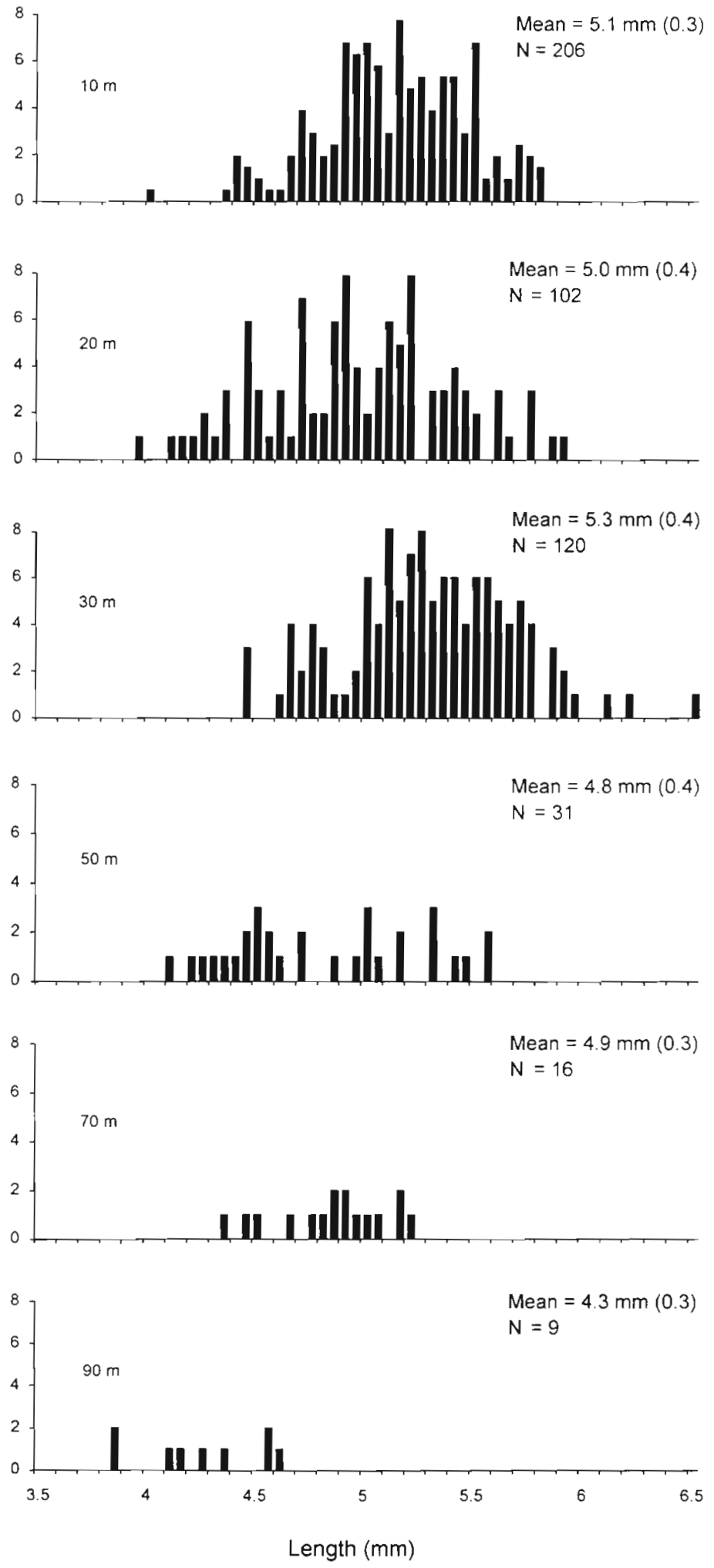

Fig. 3. Theragra chalcogramma. Length frequency distribution, mean standard length, standard deviation in parentheses, and total number, $N$, of larvae measured per depth stratum on April 20, 1992, in the oceanic domain of the Bering Sea

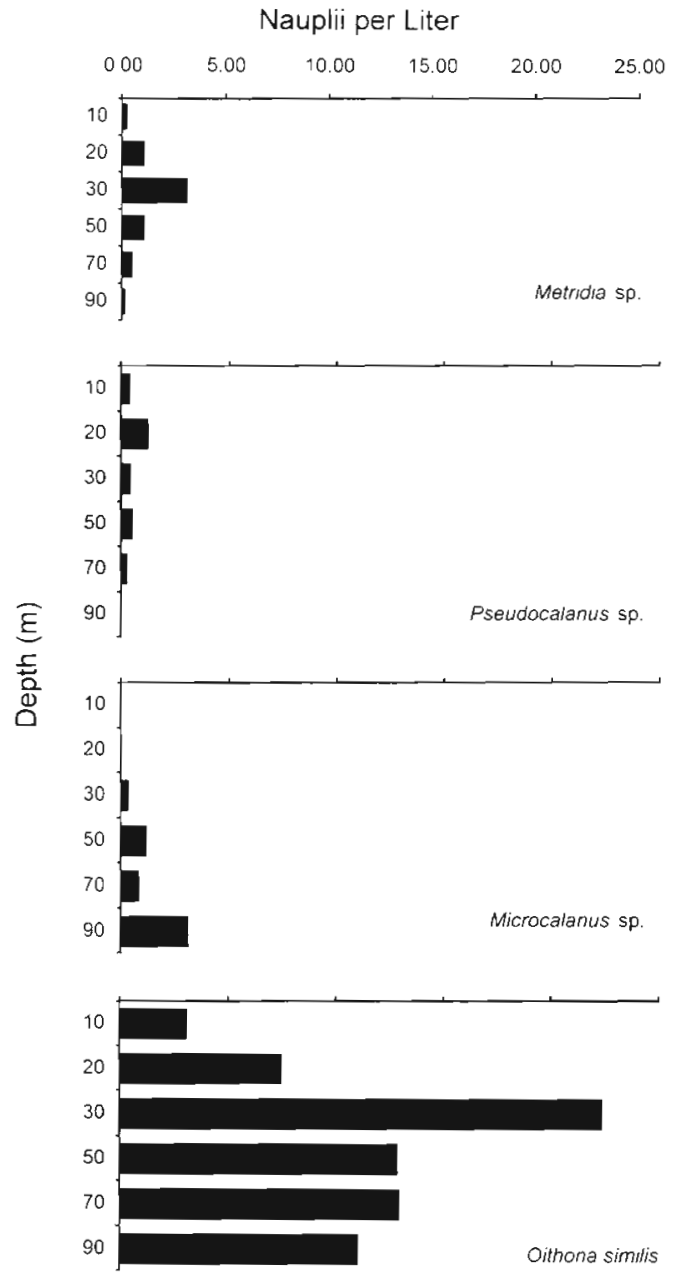

Fig. 4. Mean densities of 4 species of copepod nauplii found at the sampling station. April 20, 1992, in the oceanic domain of the Bering Sea

\section{Walleye pollock feeding}

Of 330 larval walleye pollock guts examined, $187(56.7 \%)$ contained food items. Feeding incidence varied significantly among depths $\left(\chi^{2}=\right.$ 88.85, $\mathrm{df}=5, \mathrm{p} \leq 0.001)$. The highest incidence of feeding $(97.5 \%)$ occurred at $30 \mathrm{~m}$ depth (Table 2). At all other depth strata no more than $70 \%$ of larvae were observed feeding. No feeding was observed at $90 \mathrm{~m}$ depth. The number of prey items larva ${ }^{-1}$ varied significantly among depths $(F=21.49, \mathrm{p} \leq 0.001)$ (Table 2$)$. The maximum occurred at $30 \mathrm{~m}$ depth and was significantly higher than gut contents at all other depth strata (Scheffé's a posteriori).

A total of 483 food items were identified. Weighted over all depths, Metridia sp. nauplii 
Table 2. Theragra chalcogramma. Incidence of feeding and mean number of prey larva ${ }^{-1}$ for walleye pollock larvae collected on April 20, 1992, in the oceanic domain of the Bering Sea. Means and $95 \%$ confidence intervals were calculated from square-root-transformed variates. Parentheses indicate $95 \%$ confidence intervals

\begin{tabular}{|ccl|}
\hline $\begin{array}{c}\text { Depth } \\
(\mathrm{m})\end{array}$ & $\begin{array}{c}\text { Feeding } \\
\text { incidence }(\%)\end{array}$ & Mean prey larva ${ }^{-1}$ \\
\hline 10 & 58.73 & $2.05(1.68 ; 2.46)$ \\
20 & 68.25 & $1.85(1.50 ; 2.24)$ \\
30 & 97.50 & $4.61(3.95 ; 5.31)$ \\
50 & 66.04 & $2.38(1.92 ; 2.88)$ \\
70 & 16.67 & $1.26(0.50 ; 2.24)$ \\
90 & 0 & 0 \\
\hline
\end{tabular}

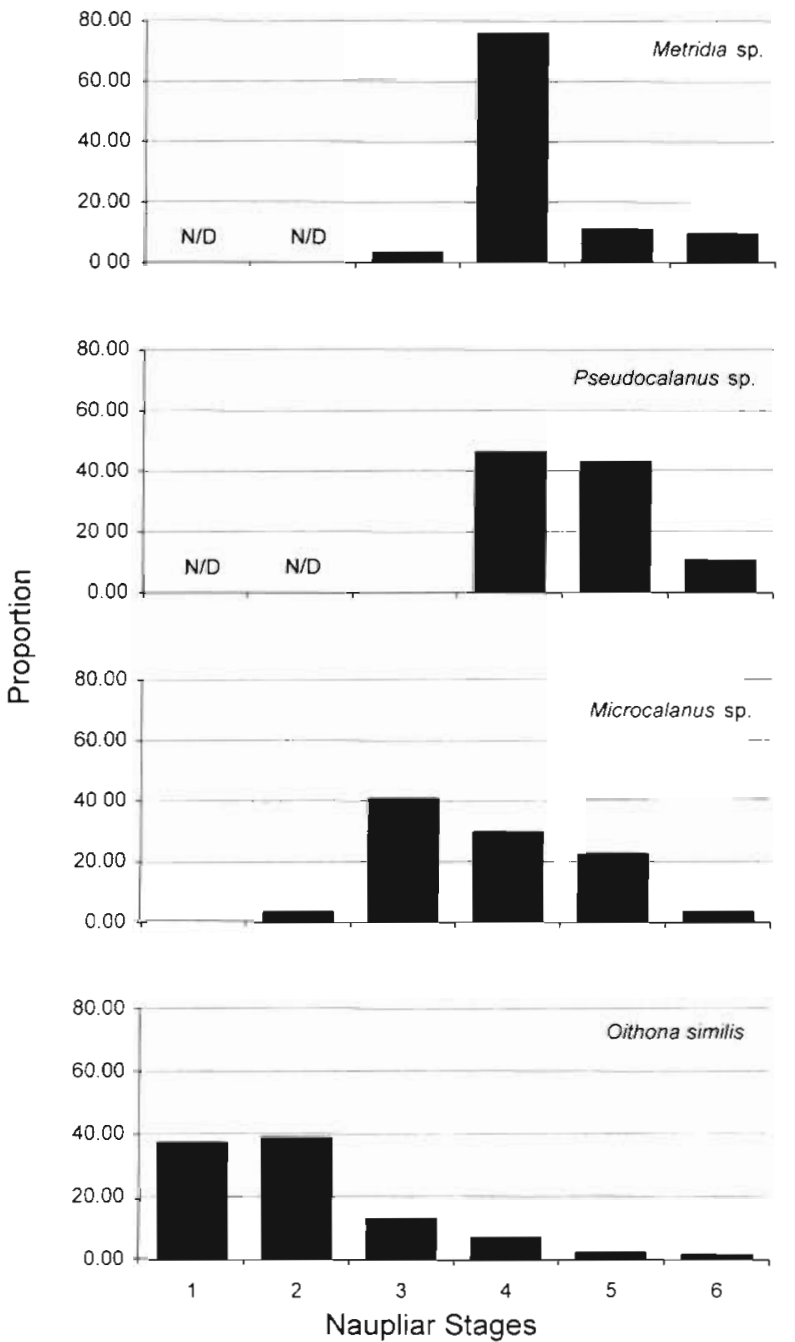

Fig. 5. Theragra chalcogramma. Overall proportion of 4 species of copepod nauplii in the diet of larval walleye pollock on April 20, 1992. N/D: not determined accounted for $28 \%$ of prey items ingested, followed by Microcalanus sp., Oithona similis, copepod eggs, and Pseudocalanus sp. nauplii with $21,18,17$, and $5 \%$, respectively.

Prey items consisted primarily of the older naupliar stages of Metridia sp. (IV), Pseudocalanus sp. (IV and V), and Microcalanus sp. (III, IV, and V); however, Oithona similis nauplii were primarily Stages I to III (Fig. 5).

Numerically, copepod nauplii were the most common food item consumed by larval walleye pollock at all depths (Table 3). Oithona similis nauplii accounted for $18.3,32.2,8.6$, and $13.5 \%$ of the diet at $10,20,30$, and $50 \mathrm{~m}$ depth, respectively, Metridia sp. nauplii for
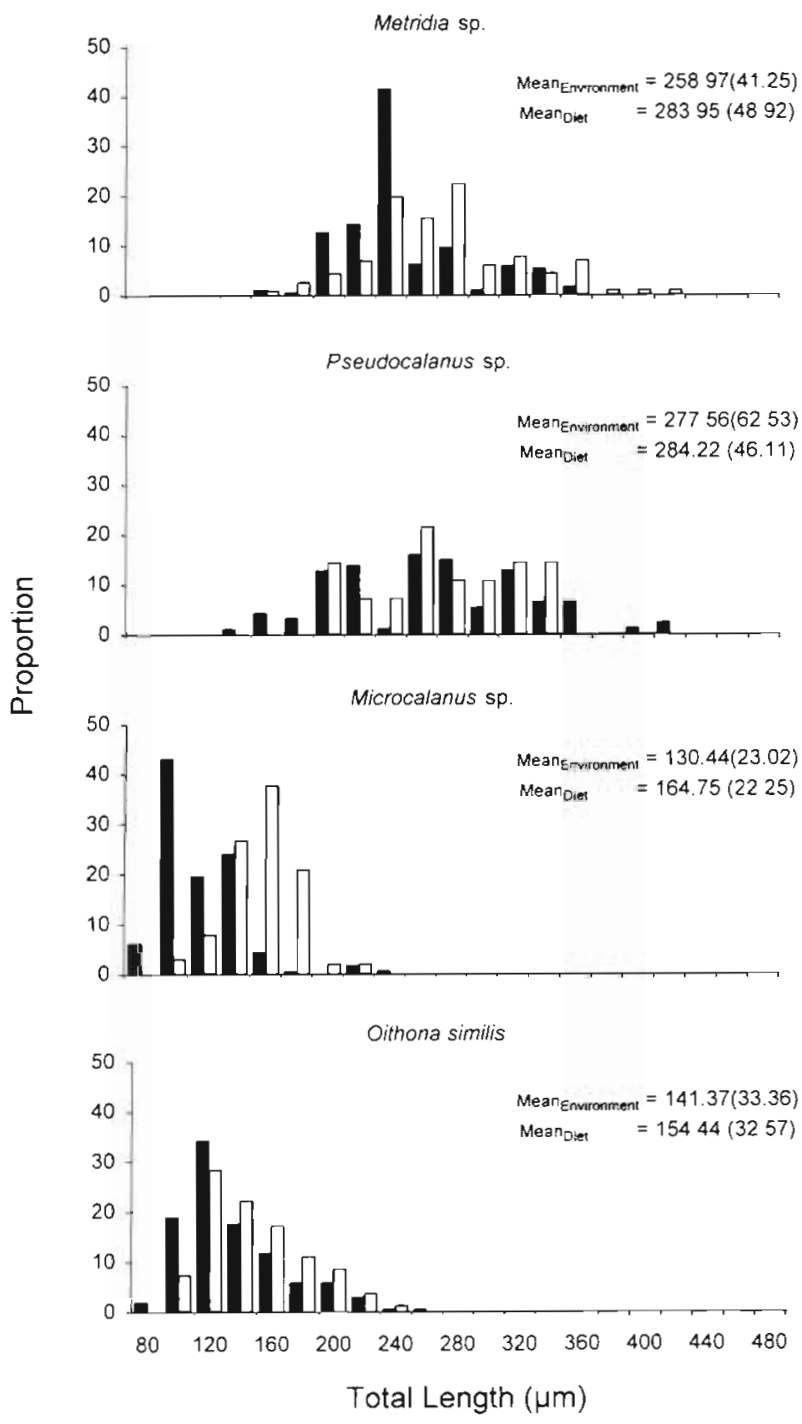

Fig. 6. Comparisons of the size frequency distributions and mean total lengths (SD) of 4 species of copepod nauplii in the diet of walleye pollock larvae (open bars) and in the water column (solid bars) on April 20, 1992 
Table 3. Theragra chalcogramma. Diet of larval walleye pollock collected on April 20,1992, in the oceanic domain of the Bering Sea, expressed as percent number ( $\% N)$, percent volume (\%Vol), and percent index of relative importance $(\% \mid R I)$

\begin{tabular}{|c|c|c|c|c|c|}
\hline $\begin{array}{l}\text { Depth } \\
\text { (m) }\end{array}$ & $N$ & Taxon & $\% \mathrm{~N}$ & $\%$ Vol & $\% I R I$ \\
\hline \multirow[t]{6}{*}{10} & \multirow[t]{6}{*}{42} & Copepod eggs & 36.6 & 48.5 & 68.3 \\
\hline & & Metridiasp. & 12.9 & 13.0 & 8.8 \\
\hline & & Pseudacalanus sp & 8.6 & 12.0 & 3.8 \\
\hline & & Microcalanus sp. & 3.2 & 1.3 & 0.3 \\
\hline & & Oithona similis & 18.3 & 11.9 & 9.3 \\
\hline & & Others & 20.4 & 13.3 & 9.5 \\
\hline \multirow[t]{6}{*}{20} & \multirow[t]{6}{*}{45} & Copepod eggs & 32.2 & 53.7 & 63.9 \\
\hline & & Metridia sp. & 4.6 & 4.3 & 0.5 \\
\hline & & Pseudocalanus sp. & 6.9 & 9.8 & 3.1 \\
\hline & & Microcalanus sp. & 12.6 & 4.7 & 3.8 \\
\hline & & Oithona similis & 32.2 & 20.3 & 24.4 \\
\hline & & Others & 11.5 & 7.2 & 4.3 \\
\hline \multirow[t]{6}{*}{30} & \multirow[t]{6}{*}{40} & Copepod eggs & 10.6 & 21.6 & 8.0 \\
\hline & & Metridia sp. & 34.3 & 44.0 & 53.5 \\
\hline & & Pseudocalanus sp. & 4.0 & 6.9 & 1.6 \\
\hline & & Microcalanus sp. & 26.3 & 9.7 & 21.6 \\
\hline & & Oithona similis & 8.6 & 10.0 & 4.9 \\
\hline & & Others & 16.2 & 7.8 & 10.4 \\
\hline \multirow[t]{6}{*}{50} & \multirow[t]{6}{*}{37} & Copepod eggs & 6.3 & 10.2 & 2.4 \\
\hline & & Metridia sp. & 32.3 & 50.4 & 60.8 \\
\hline & & Pseudocalanus sp. & 6.3 & 7.3 & 2.4 \\
\hline & & Microcalanus sp. & 35.4 & 11.9 & 27.8 \\
\hline & & Oithona similis & 13.5 & 1.4 & 4.4 \\
\hline & & Others & 6.2 & 18.8 & 2.2 \\
\hline \multirow[t]{6}{*}{70} & \multirow[t]{6}{*}{7} & Copepod eggs & 55.6 & 66.1 & 78.9 \\
\hline & & Metridia sp. & 22.2 & 29.7 & 16.8 \\
\hline & & Pseudocalanus sp. & 0.0 & 0.0 & 0.0 \\
\hline & & Microcalanus sp. & 11.1 & 3.1 & 2.3 \\
\hline & & Oithona similis & 0.0 & 0.0 & 0.0 \\
\hline & & Others & 11.1 & 1.1 & 2.0 \\
\hline
\end{tabular}

$12.9,4.6,34.3$, and $32.3 \%$, and Microcalanus sp. nauplii for $3.2,12.6,26.3$, and $35.4 \%$. Pseudocalanus sp. nauplii were rare (Table 3 ). The other item consistently found in the larval diet was copepod eggs. They accounted for 36.6 and $32.2 \%$ of the larval diet at 10 and $20 \mathrm{~m}$ depth, respectively.

Copepod eggs were most important volumetrically at 10,20, and $70 \mathrm{~m}$ depth (Table 3). The volume of Metridia sp. nauplii in the larval diet increased with increasing depth, reaching peak values $(50.4 \%)$ at $50 \mathrm{~m}$ depth. Even though high numbers of Microcalanus sp. nauplii were ingested, their volume was low because of their small size.

At 10,20 , and $70 \mathrm{~m}$ depth, copepod eggs were the prey item with the highest relative importance for walleye pollock larvae (Table 3). At 30 and $50 \mathrm{~m}$ depth Metridia sp. nauplii were predominant in the diet of pollock larvae, increasing in proportion with increasing larval length; Microcalanus sp. and Pseudocalanus $\mathrm{sp}$. were second and third in importance as prey items.

\section{Feeding selectivity}

Walleye pollock larvae significantly selected for calanoid nauplii and against the cyclopoid nauplii of Oithona similis at all depths (Table 4). Among the calanoids there was positive selection for Metridia sp. at all depths and for Microcalanus sp. nauplii at 30 and $50 \mathrm{~m}$ depths. No selectivity pattern was found for Pseudocalanus sp. nauplii. The mean size of copepod nauplii in the larval diet was greater than that of nauplii in the environment. There were significant differences between the mean TL of nauplii in the diet and

Table 4. Theragra chalcogramma. Proportion of the given prey taxa in the larval diet $\left(p_{1}\right)$ and in the environment $\left(p_{2}\right)$ for larval walleye pollock sampled on April 20,1992, in the oceanic domain of the Bering Sea. $N_{1}$ : number of prey organisms in the larval diet; $N_{2}$ : number of prey organisms in the environment. Also shown are results of the Odds Ratio analysis of food selectivity.

Parentheses indicate standard errors. Blanks are shown where too few nauplii were available. ${ }^{p} \leq 0.05 ; " p \leq 0.01$

\begin{tabular}{|c|c|c|c|c|c|c|c|c|c|c|c|c|}
\hline \multicolumn{13}{|c|}{ Proportion of prey } \\
\hline \multirow[t]{2}{*}{ Depth } & \multirow[t]{2}{*}{$N_{1}$} & \multirow[t]{2}{*}{$\mathrm{N}_{2}$} & \multicolumn{2}{|c|}{ Metridia sp. } & \multicolumn{2}{|c|}{ Pseudocalanus sp. } & \multicolumn{2}{|c|}{ Microcalanus sp. } & \multicolumn{2}{|c|}{ Oithona similis } & \multicolumn{2}{|c|}{ Others } \\
\hline & & & $p_{1}$ & $p_{2}$ & $p_{1}$ & $p_{2}$ & $p_{1}$ & $p_{2}$ & $p_{1}$ & $p_{2}$ & $p_{1}$ & $p_{2}$ \\
\hline 10 & 59 & 119 & 0.2 & 0.1 & 0.14 & 0.11 & 0.05 & 0 & 0.3 & 0.8 & 0.3 & 0 \\
\hline 20 & 59 & 312 & 0.1 & 0.1 & 0.1 & 0.12 & 0.19 & 0 & 0.5 & 0.7 & 0.2 & 0 \\
\hline 30 & 177 & 834 & 0.4 & 0.1 & 0.05 & 0.02 & 0.29 & 0.02 & 0.1 & 0.8 & 0.2 & 0 \\
\hline 50 & 90 & 505 & 0.3 & 0.1 & 0.07 & 0.03 & 0.38 & 0.09 & 0 & 0.8 & 0.2 & 0 \\
\hline \multicolumn{13}{|c|}{ Log of the Odds Ratio } \\
\hline Depth & & Metridiasp. & & \multicolumn{3}{|c|}{ Pseudocalanus sp. } & Microcala & nus sp. & \multicolumn{4}{|c|}{ Oithona similis } \\
\hline 10 & & $+1.41 \cdots(0.51)$ & & +0.25 & $(0.48)$ & & & & & $-2.45 \cdots$ & $(0.37)$ & \\
\hline 20 & & $-0.45 \quad(0.55)$ & & -0.20 & $(0.46)$ & & $+4.27 \cdots$ & $(1.06)$ & & $-1.15 \cdots$ & $(0.29)$ & \\
\hline 30 & & $+1.599^{\circ}(0.19)$ & & $+1.03^{\circ}$ & $(0.45)$ & & $+3.28 \cdots$ & $(0.32)$ & & $-3.79^{\cdots}$ & $(0.27)$ & \\
\hline 50 & & $+1.99 \cdot(0.28)$ & & +0.72 & $(0.49)$ & & $+1.85 \cdots$ & $(0.27)$ & & $-4.30 \cdots$ & $(0.52)$ & \\
\hline
\end{tabular}


in the water column for Metridia sp., Microcalanus sp. and $O$. similis ( $t$-test, $p<0.01$ ). No size differences were found for Pseudocalanus sp. nauplii (Fig. 6).

\section{DISCUSSION}

Copepod nauplii are the most important prey item for first-feeding walleye pollock larvae in the continental shelf waters of the Bering Sea (Clarke 1984. Dagg et al. 1984, Nishiyama et al. 1986), in Funka Bay (Kamba 1977, Nakatani 1991), in Shelikof Strait (Kendall et al. 1987. Canino et al. 1991), and in southeast Alaska (Sterritt 1989, Pritchett 1990). In this study, copepod nauplii and eggs comprised the diet of larval walleye pollock in the oceanic domain of the Bering Sea. Copepod eggs were consistently found in the larval diet. However, it has been suggested that copepod eggs may resist digestion in the larval digestive tract (Conway et al. 1994). In the present study, intact copepod eggs were occasionally found in the hindgut, suggesting that a proportion of the ingested eggs were lost to larval nutrition.

The highest observed density of larval walleye pollock and copepod nauplii coincided at $30 \mathrm{~m}$ depths Overall densities of copepod nauplii ranged from $3.7 \mathrm{l}^{-1}$ at $10 \mathrm{~m}$ to $27.2 \mathrm{l}^{-1}$ at $30 \mathrm{~m}$ and were consistent with densities reported from other studies (Clarke 1984, Dagg et al. 1984, Incze et al. 1990, Canino et al. 1991, Incze \& Ainaire 1994).

Successful feeding by walleye pollock larvae is a function of factors such as temperature, light and prey abundance (Paul 1983). Water temperature has a marked effect on feeding incidence in pollock larvae; Paul (1983) showed that, in the laboratory, walleye pollock larvae held at $3^{\circ} \mathrm{C}$ had a feeding incidence of $14 \%$ at 400 nauplii $1^{-1}$. At $5.5^{\circ} \mathrm{C}$, the same percentage of larvae fed at prey concentrations of $24 \mathrm{l}^{-1}$. In the southeastern Bering Sea, early life stages of walleye pollock are usually exposed to temperatures of 3.0 to $3.5^{\circ} \mathrm{C}$ (Incze et al. 1984). The water temperature at our sampling station was homogeneously cold $\left(2.8^{\circ} \mathrm{C}\right)$ in the upper $20 \mathrm{~m}$. Below $20 \mathrm{~m}$, temperature increased with increasing depth; therefore, walleye pollock larvae below $20 \mathrm{~m}$ depth encountered slightly better thermal conditions than larvae in shallower depths. Walleye pollock larvae are visual feeders with a luminance threshold for feeding of about 0.4 lux (Paul 1983). In the southeastern Bering Sea this light level is available to approximately $30 \mathrm{~m}$ depth (Olla \& Davis 1990). Pollock larvae in the present study were highly concentrated in the upper $30 \mathrm{~m}$ of the water column. Larval abundance peaked significantly at $30 \mathrm{~m}$ depth. At this depth stratum larvae apparently experienced the best available conditions: slightly warmer water, light lev- els sufficient for feeding success, and peak prey concentration.

Fish larvae discriminate among prey organisms and actively select their prey from the variety of items they encounter (Peterson \& Ausubel 1984, Jenkins 1987, Pryor \& Epifanio 1993). Selectivity may be influenced by encounter rates, prey visibility, capturability, finescale distribution of predator and prey, and preferences of predator (Jenkins 1987). Visibility characteristics of the prey could include size, shape, contrast, color, and movement (Jenkins 1987, Pryor \& Epifanio 1993). Larvae of Atlantic mackerel Scomber scombrus selected copepod nauplii by species and fed predominately on Temora longicornis nauplii (Peterson \& Ausubel 1984). Larval weakfish Cynoscion regalis in the laboratory displayed feeding selectivity that was influenced by prey size, swimming speed and patterns, and prey abundance; the selectivity pattern changed ontogenetically (Pryor \& Epifanio 1993).

Previous studies on the diet of first-feeding larval walleye pollock have not directly enumerated individual prey taxa and stages. Indirect evidence has been used to determine the species composition of the prey field but no direct identification of the copepod nauplii was undertaken. In the Gulf of Alaska the length- and width-frequency distribution of nauplii indicated that Pseudocalanus spp. and Oithona spp. were the most likely prey taxa present in guts (Kendall et al. 1987). Clarke (1984) observed that the increase of Pseudocalanus spp. copepodite biomass matched that of the nauplii biomass and concluded that Pseudocalanus spp. were a likely source of prey for walleye pollock larvae in the Bering Sea.

In this study, walleye pollock larvae significantly selected for and against certain copepod taxa and stages. The most abundant prey items in the larval diet were copepod eggs and copepod nauplii of Metridia sp. and Microcalanus sp.i positive selection occurred for both species of copepod nauplii. No selectivity pattern could be calculated for copepod eggs since no data on their abundance in the water column were collected. Even though Oithona similis nauplii were by far the most abundant species in the environment, they did not predominate in the diet of walleye pollock larvae. Pseudocalanus sp. nauplii occurred at abundances $<1 \mathrm{l}^{-1}$ at all depths, except for $20 \mathrm{~m}\left(1.3 \mathrm{l}^{-1}\right)$ in the water column. No selectivity pattern could be established, probably due to their low abundance

Nauplii of cyclopoid copepods like Oithona similis are known to have different swimming behaviors than calanoid copepods. They tend to swim in a jerky fashion as a result of the movement of their cephalic appendages, while calanoid copepod nauplii swim in a smoother pattern (Pryor \& Epifanio 1993). The irregular swimming pattern of cyclopoids may serve as a 
visual attractant for some foraging fish larvae (Govoni et al. 1983). However, the first naupliar stages of Oithona plumifera, a cyclopoid, are characterized by long periods of non-swimming, thus reducing the chance of being detected by larval fishes (Buskey et al. 1993). Since, in this study, calanoid nauplii were chosen over cyclopoid nauplii, we surmise that the smooth swimming style and high activity of calanoid nauplii may be more perceptible for first-feeding pollock larvae.

Copepod eggs were consumed in high numbers. However, since no data on egg abundance in the water column were available, we can only hypothesize that walleye pollock larvae encountered them by chance.

Metridia sp. nauplii ranged in size from ca 150 to $400 \mu \mathrm{m}$ total length, whereas Microcalanus sp. nauplii were 80 to $250 \mu \mathrm{m}$ total length. Thus, prey size cannot be the common characteristic for selection of Metridia sp. and Microcalanus sp. nauplii. Also, the size ranges of Microcalanus sp. and Oithona similis nauplii are similar. If size was the basis for selection it is unlikely that walleye pollock larvae would select for one and against the other. However, within taxa, walleye pollock larvae did select proportionately larger and older prey than occurred in the water column. Thus, while size or stage selection appears to operate within a given taxon it does not explain the selection among the available taxa. In previous studies fish larvae selected strongly for prey size, but consumed prey taxa of similar size relatively indiscriminately (Theilacker \& Dorsey 1980). In the present study the opposite occurred - fish larvae selected for prey size or stage if the prey taxon was suitable.

Suboptimal food levels may regulate survival of larval fish through reduced growth rates and prolonged stage duration, especially affecting first-feeding larvae (Houde 1987). High densities of prey organisms, on the other hand, may enhance growth rates and increase survival of larval fish. Clarke (1984) suggested that differences in larval pollock growth rates in the Bering Sea were related to differences in food abundance. In Shelikof Strait, gut fullness and RNA/DNA values of walleye pollock larvae were positively related to copepod nauplii density (Canino et al. 1991). In the present study, feeding intensity and concentration of copepod nauplii were depth dependent and highest at $30 \mathrm{~m}$ depth. Feeding incidence of walleye pollock larvae peaked at $30 \mathrm{~m}$ depth. At all other depths no more than $70 \%$ of larvae were observed feeding. The overall percentage of larvae feeding was only $56.7 \%$ and was therefore far below values observed in other studies in the southeastern Bering Sea, e.g. Nishiyama et al. (1986) observed 77 to $98 \%$ and Dagg et al. (1984) 95\% feeding walleye pollock larvae.

The mean numbers of prey items larva ${ }^{-1}$ ranged from 2 items at the surface to a peak value of 4.6 items at $30 \mathrm{~m}$ depth. This value is somewhat below that of other studies. Nishiyama et al. (1986) observed 4.2 to 6.7 food items in 3.5 to $5.5 \mathrm{~mm}$ larvae and Clarke (1984) found 6.1 items per gut. In the Gulf of Alaska, the mean number of prey per walleye pollock larvae ranged from 2.25 to 9.32 (Canino et al. 1991). In Auke Bay, southeast Alaska, the mean number of prey items for larvae hatched prior to the herbivorous copepod maximum was 3.7 and 7.0 larva $^{-1}$ for larvae that occurred simultaneously with maximum densities of herbivorous copepods (Sterritt 1989).

Since the mean volumes of prey found in the guts of walleye pollock larvae increased during the day and decreased during the evening, with no decline during midday (Haldorson et al. 1990), our sampling should have caught larvae at the peak of feeding. Therefore, overall feeding incidence and numbers of items ingested suggest poor foraging conditions compared to walleye pollock larvae in other areas (Clarke 1984, Nishiyama et al. 1986, Sterritt 1989).

In addition, it seems no longer sufficient to simply count the number of copepod nauplii in order to characterize the prey field. In our study, walleye pollock larvae showed significant preferences for and against certain taxonomic groups. Therefore, it seems essential to identify the copepod nauplii to the lowest possible taxon in order to properly define the foraging environment for walleye pollock larvae.

Acknowledgements. Funding for this study was provided by the National Marine Fisheries Service under the Bering Sea FOCI (Fisheries-Oceanography Cooperative Investigations) program. We thank K. Coyle and J. Paul for helping tremendously with the identification of the copepod nauplii. We also thank $H$. v. Westernhagen and $M$. Kloppmann for helpful comments on the manuscript.

\section{LITERATURE CITED}

Buskey, E. J., Coultier, C., Strom, S. (1993). Locomotory patterns of microzooplankton: potential effects on food selectivity of larval fish. Bull. mar. Sci. 53(1): 29-43

Canino, M. F., Bailey, K. M., Incze, L. S. (1991). Temporal and geographic differences in feeding and nutritional condition of larval walleye pollock. Theragra chalcogramma, in the Shelikof Strait, Gulf of A.laska. Mar. Ecol. Prog. Ser. 79 . $27-35$

Clarke, M. E. (1984). Feeding behavior of larval walleye pollock, Theragra chalcogramma (PALLAS) and food availability to Iarval pollock in the southeastern Bering Sea. Ph.D. thesis, University of California, San Diego

Conway, D. V. P., McFadzen, I. R. B., Tranter, P. R. G. (1994). Digestion of copepod eggs by larval turbot Scophthalmus maximus and egg viability following gut passage. Mar. Ecol. Prog. Ser. 106: 303-309

Cooney, R. T., Coyle, K. O. (1982). Trophic implications of cross-shelf copepod distributions in the southeastern Bering Sea. Mar. Biol. 70: 187-196

Crecco, V. A., Savoy, T. (1987). Review of recruitment mechanisms of the American shad: the critical period and match- 
mismatch hypothesis reexamined. Am. Fish. Soc. Symp. 1. $455-468$

Dagg, M. J., Clarke, M. E., Nishiyama, T., Smith, S. L. (1984). Production and standing stock of copepod nauplii, food items for the walleye pollock Theragra chalcogramma in the southeastern Bering Sea. Mar. Ecol Prog. Ser 19:7-16

Frank, K. T. (1988). Independent distributions of fish larvae and their prey: natural paradox or sampling artifact? Can. J. Fish. Aquat. Sci. 45: 48-59

Frank, K. T., Leggett, W. C. (1986). Effect of prey abundance and size on the growth and survival of larval fish: an experimental study employing large volume enclosures. Mar. Ecol. Prog. Ser. 34: 11-22

Gabriel, W. L. (1978). Statistics of selectivity. In: Gutshop '78. Fish food habit studies. Proceedings of the second Pacific northwest technical workshop. Washington Sea Grant, Division of Marine Resources, University of Washington H-30, Seattle, p. 62-66

Govoni, J. J., Hoss, D. E., Chester, A. J. (1983). Comparative feeding of three species of larval fishes in the northern Gulf of Mexico: Brevoortia patronus, Leiostomus xanthurus, and Micropogonias undulatus. Mar. Ecol. Prog. Ser. 13: $189-199$

Grover, J. J. (1990). Feeding ecology of late-larval and earlyjuvenile walleye pollock Theragra chalcogramma from the Gulf of Alaska in 1987. Fish. Bull. U.S. 88: 463-470

Grover, J. J. (1991). Trophic relationship of age-0 and age-1 walleye pollock Theragra chalcogramma collected together in the eastern Bering Sea. Fish. Bull. U.S. 89: $719-722$

Haldorson, L., Pritchett, M., Sterritt, D., Watts, J. (1990). Interannual variation in the recruitment potential of larval fishes in Auke Bay, Alaska. In: Ziemann, D. A., FultonBennett, K. W. (eds.) APRISE - Interannual variability and fisheries recruitment. The Oceanic Institute, Honolulu, p. 319-356

Hinckley, S. (1987). The reproductive biology of walleye pollock, Theragra chalcogramma, in the Bering Sea, with reference to the spawning stock structure. Fish. Bull. U.S. 85(3): $481-498$

Houde, E. D. (1987). Fish early life dynamics and recruitment variability. Am. Fish. Soc. Symp. 2: 17-29

Incze, L. S., Ainaire, T. (1994). Distribution and abundance of copepod nauplii and other small $(40-300 \mu \mathrm{m})$ zooplankton during spring in Shelikof Strait, Alaska. Fish. Bull. U.S. 92: $67-78$

Incze, L. S., Clarke, M. E., Goering, J. J., Nishiyama, T., Paul, A. J. (1984). Eggs and larvae of walleye pollock and relationships to the planktonic environment. In: Ito, D. H. (ed.) Proceedings of the workshop on walleye pollock and its ecosystems in the eastern Bering Sea. NOAA Tech. Memo. NMFS-F/NWC-62, Northwest \& Alaska Fish. Cent., NMFS, Seattle, p. 109-159

Incze, L. S., Ortner, P. B., Schumacher, J. D. (1990). Microzooplankton, vertical mixing and advection in a larval fish patch. J. Plankton Res. 12(2): 365-379

Jenkins, G. P. (1987). Comparative diets, prey selection, and predatory impact of co-occurring larvae of two flounder species. J. exp. mar. Biol. Ecol. 110: 147-170

Kamba, M. (1977). Feeding habits and vertical distribution of walleye pollock, Theragra chalcogramma (PALLAS), in early life stage in Uchiura Bay, Hokkaido. Res. Inst. N. Pac. Fish., Hokkaido Univ., Spec. Vol., p. 175-197

Kendall, A. W. Jr, Clarke, M. E., Yoklavich, M., Boehlert, G (1987). Distribution, feeding and growth of larval walleye pollock, Theragra chalcogramma, from Shelikof Strait, Gulf of Alaska. Fish. Bull. U.S. 85: 499-521
Kendall, A. W., Nakatani, T. (1992). Comparisons of early-lifehistory characteristics of walleye pollock Theragra chalcogramma in Shelikof Strait, Gulf of Alaska and Funka Bay, Hokkaido, Japan. Fish. Bull. U.S. 90: 129-138

Kinder, T H., Schumacher, J. D. (1981). Circulation over the continental shelf of the southeastern Bering Sea. In: Hood D. W. Calder, J. A. (eds.) The eastern Bering Sea shelf: oceanography and resources, Vol. 1. U.S. Gov. Print. Off., Washington, DC, p. 53-75

Nakatani, T. (1991). Copepod nauplii as food for walleye pollock larvae (Pisces: Gadidae) in Funka Bay, Japan. Bull. Plankton Soc. Japan, Spec. Vol.: 515-525

Nishiyama, T., Hirano, K. (1983). Estimation of zooplankton weight in the gut of larval walleye pollock (Theragra chalcogramma). Bull. Plankton Soc. Japan 30(2): 159-170

Nishiyama, T., Hirano, K., Haryo, T. (1986). The early life history and feeding habits of larval walleye pollock Theragra chalcogramma (PALLAS) in the southeastern Bering Sea. Symposium on biology, stock assessment, and management of pollock, Pacific cod and hake in the North Pacific region. Bull. INPFC 45: 177-227

Ogilvie, H. S. (1953). Zooplankton. Rapp. P.-v. Réun. Cons. perm. int. Explor. Mer, Sheet 50: 1-4

Olla, B. L., Davis, M. W. (1990). Effects of physical factors on the vertical distribution of larval walleye pollock Theragra chalcogramma under controlled laboratory conditions. Mar. Ecol. Prog. Ser. 63: 105-112

Paul, A. J. (1983). Light, temperature, nauplii concentration, and prey capture by first feeding pollock larvae Theragra chalcogramma. Mar. Ecol. Prog. Ser. 13: 175-179

Peterson, W. T., Ausubel. S. J. (1984). Diets and selective feeding by larvae of Atlantic mackerel Scomber scombrus on zooplankton. Mar. Ecol. Prog. Ser. 17: 65-75

Pritchett, M. S. (1990). Ichthyoplankton vertical distribution and vertical migration in Auke Bay, Alaska. M.S. thesis, University of Alaska, Fairbanks

Pryor, V. K., Epifanio, C. E. (1993). Prey size selection by larval weakfish (Cynoscion regalis): the effects of prey size, speed, and abundance. Mar. Biol. 116: 31-37

Sazhina, L. I. (1985). Naupliusy massovykh vidov pelagicheckikh kopepod Mirovogo okeana. Npukova Dumka Press, Kiev, p. 3-238

Shima, M., Bailey, K. M. (1994). Comparative analysis of ichthyoplankton sampling gear for early life stages of walleye pollock (Theragra chalcogramma). Fish. Oceanogr. 3(1): 50-59

Smith, P. E., Richardson, S. L. (1977). Standard techniques for pelagic fish egg and larva surveys. FAO Fish. tech. Pap. 175

Sokal, R. R., Rohlf F. J. (1981). Biometry. W. H. Freeman and Co., San Francisco

Springer, A M. (1992). A review: walleye pollock in the North Pacific - how much difference do they really make? Fish. Oceanogr. 1(1): 80-96

Sterritt, D. A. (1989). Feeding and growth of seasonal cohorts of larval walleye pollock (Theragra chalcogramma) in Auke Bay, Alaska. M.Sc. thesis, University of Alaska, Fairbanks

Theilacker, G., Dorsey, K. (1980). Larval fish diversity, a summary of laboratory and field research. UNESCO, Int. Oceanogr. Comm. Workshop Rep. 28: 105-142

Wallace, R. K. (1981). An assessment of diet-overlap indexes. Trans. Am. Fish. Soc. 110: 72-76

Wiebe, P., Bust, K. H., Boyd, S. H., Morton, A. W. (1976). A multiple opening and closing net and environmental sensing system for sampling zooplankton. J. mar. Res. 34: $313-326$

Manuscript first received: August 8, 1994

Revised version accepted: December 13, 1994 